\title{
Protection of intellectual property rights on the Internet: new challenges
}

\section{Захист прав інтелектуальної власності у мережі Інтернет: нові виклики}

Received: May 20, 2021

Accepted: June 16, 2021

\author{
Written by: \\ Olesia Kharchenko ${ }^{79}$ \\ https://orcid.org/0000-0001-5925-955X \\ Olha Kronda ${ }^{80}$ \\ https://orcid.org/0000-0002-8039-1763 \\ Inha Kryvosheyina ${ }^{81}$ \\ https://orcid.org/0000-0003-3630-2257 \\ Kostiantyn Zerov ${ }^{82}$ \\ https://orcid.org/0000-0003-2916-7528
}

\begin{abstract}
Given the steady growth in demand for Internet resources (due to specific benefits for users) a significant issue is the governing regulation of relations that develop during the interaction of subjects of legal relations on this sphere. Intellectual property law expands the scope of regulation of legal relations via the Internet. In this regard, there is an essential need for a comprehensive study of theoretical and practical aspects of the protection of intellectual property rights on the Internet. During the study, a number of general scientific methods were used: method of observation, method of comparison, method of experiment, method of convergence from abstract to concrete, method of formalization, axiomatic method, method of analysis, and historical method. As a result of the study, the peculiarities of legal regulation of relations arising in the process of using objects of intellectual property rights on the Internet, which are caused by the difficulty in identifying the infringer of intellectual property rights, determining the place of the crime, the speed of spread of intellectual property on the Internet, low level of legal culture of the population. The ways to improve the system of protection of intellectual property rights on the Internet are the following were suggested.
\end{abstract}

\begin{abstract}
Анотація
Зважаючи на постійне зростання попиту на інтернет-ресурси, що пояснюється певними вигодами для користувачів, необхідним питанням постає нормативне регулювання відносин, що складаються під час взаємодії суб'єктів правовідносин у цій сфері. Право інтелектуальної власності розширює сферу регулювання правовідносин через мережу Інтернет. У зв'язку з цим нагальною потребою $\epsilon$ всебічне вивчення теоретичних та практичних аспектів сфери захисту прав інтелектуальної власності у мережі Інтернет. Під час проведення дослідження було використано ряд загальнонаукових методів: метод спостереження, метод порівняння, метод експерименту, метод сходження від абстрактного до конкретного, метод формалізації, аксіоматичний метод, метод аналізу, історичний метод. У результаті дослідження було з'ясовано особливості правового регулювання відносин, що виникають у процесі використання об'єктів права інтелектуальної власності у мережі Інтернет, які зумовлюються складністю у виявленні порушника прав інтелектуальної власності, визначення місця вчинення злочину, швидкістю поширення об'єктів інтелектуальної власності у мережі Інтернет, низьким рівнем правової культури населення.
\end{abstract}

\footnotetext{
${ }^{79}$ Ph.D., Associate Professor of Intellectual Property and Information Law Department, Taras Shevchenko National University of Kyiv. Ukraine.

${ }^{\mathbf{8 0}}$ Ph.D., Associate Professor of Intellectual Property and Information Law Department, Taras Shevchenko National University of Kyiv, Ukraine.

${ }^{81}$ Associate Professor of Intellectual Property and Information Law Department, Taras Shevchenko National University of Kyiv, Ukraine.

${ }^{82}$ Ph. D., Assistant Professor of Intellectual Property and Information Law Department, Taras Shevchenko National University of Kyiv, Ukraine.
} 


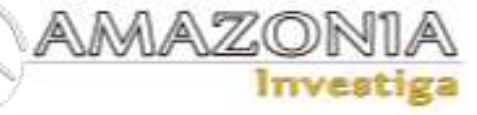

Keywords: intellectual property law, Internet, protection of intellectual property rights, user, subject of legal relations.
Серед шляхів удосконалення системи захисту прав інтелектуальної власності у мережі Інтернет запропоновано наступні були запропоновані.

Ключові слова: право інтелектуальної власності, мережа Інтернет, захист прав інтелектуальної власності, користувач, суб'єкт правовідносин.

\section{Introduction}

The Internet, as an international public telecommunications network designed for data exchange, has quickly entered the daily life of society (Petrovsky, 2002). The main advantages of using the Internet include the following (Inshin, 2008):

- the ability to quickly find the necessary information at any time and in any place;

- efficiency of obtaining information;

- the capacity of legal entities and individuals to increase the audience that is interested in the relevant content;

- the ability to quickly establish feedback via the Internet.

According to TV Technology, citing the Buy Shares report, the number of Internet users has grown by 297 million over the past year. In total, it has 4.8 billion people, which is about $63 \%$ of the world's population (Mind, 2020).

Due to the extreme prevalence of the use of the Internet, the legal regulation of intellectual property has also shifted from tangible to virtual media.

The rapid growth of infringements of intellectual property rights on the Internet and the problems of their legal regulation have led to the search for solutions to combat such illegal actions. In the developed world, effective mechanisms have been put in place to promote the protection of intellectual property rights, in particular, by requiring ISPs (Internet Service Provider) to disclose confidential information about alleged copyright infringers and transfer such data to the appropriate authorities. At the national level, non-profit organization "Ukrainian Anti-Piracy Association" (2021), which activities are aimed at developing and improving legislation on copyright and related rights, and other areas of law governing the creation, use, and protection of rights to intellectual property, assistance to law enforcement and other government agencies in identifying cases of copyright and other rights and interests of its members, including by carrying out preventive work to prevent such violations, as well as by developing guidelines for law enforcement activities in this field, etc.

However, these methods of combating and preventing infringements of intellectual property rights on the Internet are not effective enough, as evidenced by the above statistics and existing case law.

Given this, it is essential to analyze the legal framework for the protection of intellectual property rights on the Internet, to identify the main types of copyright infringement on the Internet, mechanisms to combat such infringements, ways to record illegal actions infringing intellectual property rights on the Internet. Also, based on the existing unresolved issues in the field of intellectual property protection on the Internet, it is vital to make proposals to improve the protection of such rights.

The purpose of the work is to study and analyze the state of protection of intellectual property rights on the Internet. The object of research is the protection of intellectual property rights on the Internet. The subject of the study is public relations in the field of protection of intellectual property rights on the Internet.

\section{Theoretical Framework}

The matter of protection of intellectual property rights on the Internet requires a comprehensive study and analysis of regulations, both international and domestic.

The study used the provisions of the Convention Establishing the World Intellectual Property Organization of July 14, 1967, the principal purpose of which is to promote the protection of intellectual property worldwide. It contains norms on the definition of intellectual property, determines the functions of the World Intellectual Property Organization, determines 
the order of membership in the organization, the order of its work, the structural organization.

The Patent Law Treaty of June 1, 2000, and the Strasbourg Agreement Concerning the International Patent Classification of March 24, 1971, concern the regulation of patents. In particular, they established a procedure for determining the date of filing a patent application, as well as the form and content of this application, all inventions are divided into 8 main sections, and the number of small headings is more than 50 thousand titles. The International Patent Classification System is used not only by the countries that have officially joined it but also by many others.

The WIPO Performance and Phonograms Treaty of December 20, 1996, and the International Convention for the Protection of Performers, Producers of Phonograms and Broadcasting Organizations of October 26, 1961, set out the fundamental provisions on the legal regime for performances and phonograms. In particular, the regulation of such concepts as performers, phonogram, recording, phonogram producer, etc.; identified entities whose rights are protected by the international definition of the scope of performance and phonograms, their rights and responsibilities, and other provisions.

The cooperation of Ukraine in the field of intellectual property with other countries is essential for raising the professional level of legislative and practical implementation of the practice of foreign countries in this field. An example of such cooperation is the Agreement between the Cabinet of Ministers of Ukraine and the Government of the Republic of Uzbekistan on cooperation in the field of intellectual property rights of February 19, 1998, where the main principles of cooperation between the two countries are the exchange of legal information, as well as information on the practice of application of legislation in the field of intellectual property rights, exchange of information on experience in intellectual property, training and retraining of personnel in the field of intellectual property rights, exchange experience of this work, etc.

When considering disputes over domain names by courts, judges use the following international acts:

- WIPO Report "Name and Address Management and the Internet: Intellectual Property Issues";
- Joint Recommendation on the Protection of Well-known Marks, adopted by the Paris Union Assembly for the Protection of Industrial Property and the General Assembly of the World Intellectual Property Organization at the 34th series of meetings of the Assembly of the Member States of the World Intellectual Property Organization on 20-29 September 1999;

- Joint Recommendation "On the Protection of Marks and Other Industrial Property Rights on Internet Designations", adopted by the Paris Union Assembly on Industrial Property Protection and the General Assembly of the World Intellectual Property Organization at the 36th meeting of the Assembly of Member States of the World Intellectual Property Organization property September 24 - October 3, 2001.

It should be noted that the above documents are not binding on the territory of Ukraine and are recommendatory.

Regarding national legislation, the main provisions on intellectual property in Ukraine are contained in the following regulations:

- Constitution of Ukraine of June 28, 1996 (Article 41 and Article 54) (Law No. 254к/96-BP 1996);

- Laws of Ukraine "On Copyright and Related Rights" of December 23, 1993, "On Television and Radio Broadcasting" of December 21, 1993, "On Telecommunications" of November 18, 2003, "On Protection of Rights to Marks for Goods and Services" of December 15, 1993.

Codified normative legal acts establish liability for infringement of intellectual property rights (Criminal Code of Ukraine of April 5, 2001 (Law No. 2341-III, 2001), Code of Ukraine on Administrative Offenses of December 7, 1984 (Law No. 8073-10, 1984), regulate legal relations in the field of intellectual property (Civil Code of Ukraine of January 16, 2003 (Law No. 435-IV, 2003), Commercial Code of Ukraine of January 16, 2003 (Law No. 436-IV, 2003)).

Resolution of the Plenum of the Supreme Court of June 4, 2010, No. 5 "On the application by courts of legislation in cases of protection of copyright and related rights", Resolution of the Plenum of the Supreme Commercial Court of Ukraine October 17, 2012, No. 12 "On some issues of dispute resolution protection of intellectual property rights" contain provisions 


\section{AMAZONDA}

on the peculiarities of resolving disputes related to intellectual property rights.

Among the scientists who studied the field of protection and enforcement of intellectual property rights on the Internet, it should be noted Zerov (2013, 2016, 2018), Sotnyk (2021), Grigoryants (2014), Kovalenko (2018), Boshytsky (2002), Yanitskaya, Ambrush, \& Koval (2019), Litavsky (2020), and Bukhtiyarov (2021). In its study on copyright protection on the Internet identified some issues related to the protection of copyright on the Internet from piracy, the solution of which in the future will minimize the occurrence of such offenses, indicated what are the gaps in the legislation, what society should pay attention to, and what specialists should be involved to prevent copyright infringement on the Internet.

Thus, Zerov $(2013,2016,2018)$ devoted a large number of works on the protection of intellectual property rights on the Internet. Recording the content of a web page on the Internet as an element of exercising the right to copyright protection of works posted on the Internet. These works studied the methods of recording infringements in the field of intellectual property on the Internet, the features of copyright objects that are placed on the Internet, revealed the essence of legal regulation of intellectual property in general and the Internet in particular. Moreover, Sotnyk (2021) analyzed the current legislation in the field of intellectual property, identified the most common types of violations of intellectual property rights on the Internet, proposed mechanisms for recording such offenses, etc.

Besides, Grigoryants (2014) came to the conclusion that the legislation of Ukraine on protection against piracy in copyright and related rights mostly meets international standards. Several problems arise when these provisions need to be implemented. For example, in the field of proof of infringement, a search of persons guilty of infringements of copyright and related rights.

Further, Boshytsky's (2002) research "Deepening the legal culture of citizens as a means of optimizing the protection of intellectual property in Ukraine" helped to clarify the role of the legal culture of Internet consumers in the illegal distribution of intellectual property rights. Finally, the general doctrines on the protection of intellectual property rights include the works of Litavsky (2020), Zheleznyakova (2021) and Bukhtiyarov (2021).
Despite a large number of works in the field of intellectual property in general and the protection of such rights on the Internet, the topic of creating a specialized judicial body, whose powers included the consideration of cases in the field of intellectual property; in the context of the above issue, the issue of training, which will be useful in the case by courts or other bodies or organizations; the expansion of legislation concerning the protection and enforcement of intellectual property rights on the Internet also requires doctrinal study.

\section{Methodology}

Methods of scientific research are an integral part of any research and help to make it effective for the practical implementation of the results of the work, logically build the presentation of material to increase the doctrinairely important achievements of legal science.

During the study, many general scientific methods were used (empirical research methods, theoretical research methods, and halls).

Among the methods of empirical research used:

- method of observation. Based on its essence, which is to identify the external features of the object under study, the protection of intellectual property rights, which has its specific features, is considered in terms of existing doctrines, followed by the addition of their proposals;

- the method of comparison, which is mostly used in scientific research, came in handy when studying foreign experience in the protection of intellectual property rights on the Internet. Thus, some valid principles were identified, which are absent in the domestic system of protection of intellectual property rights on the Internet;

- method of experiment. In particular, its form was used as an experiment for formation. Thus, it allowed to suggest ways to improve the legal regulation of relations in the field of protection of intellectual property rights on the Internet by systematically varying the state of this area;

The methods of theoretical research used to obtain practical research results include:

- the method of convergence from the abstract to the concrete used in identifying the features of protection of intellectual property rights on the Internet as a specific part of the study, protection, and enforcement of 
intellectual property rights, in general, is an abstract concept in the context of this method of research;

- the method of formalization as an integral part of formal logic during this study helped to systematize the forms of protection of intellectual property rights and to reveal their content in the most specific and concise form;

- the axiomatic method was used as a theoretical basis for intellectual property rights, referring to established international regulations and doctrinal acquisitions;

Among the general methods used were:

- analysis. This method accompanied the study throughout the process. Thus, every fact of the availability of this or that information on the approaches and statements that cover the field of intellectual property rights on the Internet;

- the historical method was used to review the means of development and improvement of legal regulation of intellectual property on the Internet, given the constant complexity of the processes occurring in the global network.

\section{Results and Discussion}

\section{Intellectual property law: legislative basis and theory}

The need to ensure efficient protection of intellectual property rights, a large number of influential legal nuances, and the presence of serious problems related to this area have contributed to the emergence of numerous international treaties, agreements, conventions, declarations, and other regulations on fundamental issues of protection and enforcement of intellectual property. The sphere of public law is, first of all, a question of subordination of one person to another, a question of competence of state bodies and officials, on the one hand, - and, on the other, passive, as a rule, legal personality of subordinates, their duties and responsibilities arising from government acts of state bodies and officials (Kharytonov, Kharytonova, Kolodin, \& Tkalych, 2020).

According to Art. 1 of the Protocol to the Convention for the Protection of Human Rights and Fundamental Freedoms of 1950, every natural or legal person is entitled to the peaceful enjoyment of his possessions. In the current reality, in interpreting this Convention, the
European Court of Human Rights (ECtHR) takes the view that this article concerns not only directly property rights but also intellectual property rights, including patents.

On July 14, 1967, the Convention on the Establishment of the World Intellectual Property Organization was signed, and on April 26, 1970, it entered into force for Ukraine. This Convention, first, establishes an international organization such as the World Intellectual Property Organization (WIPO) and, second, provides, inter alia, a definition of intellectual property. In particular, according to Art. 2 of this Convention, intellectual property is the rights to literary, artistic, and scientific works, to the performance of artists, sound recordings, the radio and television programs, to inventions in all spheres of human activity, scientific discoveries, industrial designs, trademarks, service marks, brand names, and commercial designations, to protect against unfair competition, as well as all other rights related to intellectual activity in the industrial, scientific, literary and artistic fields.

Other international treaties in the field of intellectual property concern its aspects such as patent law (Patent Law Treaty of June 1, 2000, Strasbourg Agreement on the International Patent Classification of March 24, 1971), performance, and phonograms (WIPO Performance and Phonograms Treaty of December 20, 1996, International Convention for the Protection of Performers, Producers of Phonograms and Broadcasting Organizations of October 26, 1961), etc. Numerous bilateral agreements and arrangements, such as the Agreement between the Cabinet of Ministers of Ukraine and the Government of the Republic of Uzbekistan on Cooperation in the Field of Intellectual Property Protection of February 19, 1998, which establish the basic principles of interstate cooperation in the field of intellectual property protection.

The Constitution of Ukraine (Law No. 254к/96BP, 1996) enshrines the guiding provisions concerning the protection of intellectual property directly in two articles. Art. 41 establishes the rights of possession, use, and disposal of their property, the results of their intellectual and creative activities. Article 54 guarantees citizens freedom of literary, artistic, scientific, and technical creativity, protection of intellectual property, their copyrights, moral and material interests arising in connection with various types of intellectual activity. In addition, in this article, the Constitution prohibits the dissemination or use of the results of another's intellectual, 


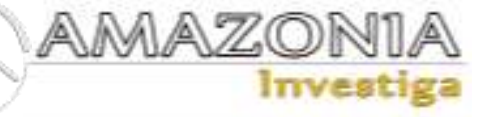

creative activity without the consent of the owner, except as provided by law.

Among the codified regulations governing this issue is the Civil Code of Ukraine (Law No. 435IV, 2003) (intellectual property law is devoted to Book Four of the Civil Code of Ukraine, which, in particular, contains such key provisions as the definition of intellectual property rights, objects and subjects, the grounds for intellectual property rights, personal non-property and intellectual property rights, etc.), the Commercial Code of Ukraine (Law No. 436-IV, 2003) (Chapter 16 regulates the use of intellectual property rights in economic activities, in particular, contains rules on intellectual property rights, the powers of business entities to objects of intellectual property rights), Code of Ukraine on Administrative Offenses (Law No. 8073-X, 1984) (contains rules on the following components of administrative offenses in the field of copyright relations: Article 51-2 - illegal use of intellectual property; Article 164-7 violation of the conditions of distribution and showing of films provided by the state certificate of the right to distribute and show films; Article 164-9 - illegal distribution of copies of audiovisual works, phonograms, videograms, computer programs, databases; Articles 164-17violation of the conditions and rules governing the termination of copyright infringement and (or) related rights using the Internet; Article 16418 - providing knowingly inaccurate information in applications for termination of copyright and (or) related rights committed using the Internet), The Criminal Code of Ukraine (Law No. 2341III, 2001) (provides for liability for illegal reproduction, distribution of works of science, literature, and art, computer programs, and databases, as well as illegal reproduction, distribution of performances, phonograms, videograms and broadcasting programs, their illegal reproduction and distribution on audioand videotapes, diskettes, other media, camcording, card sharing or other intentional infringement of copyright and related rights, as well as the financing of such actions, if it caused material damage in a significant amount).

At the level of judicial practice for the regulation of copyright relations on the Internet are leading the decision of the Plenum of the Supreme Court of Ukraine of June 4, 2010 (Resolution No. 5, 2010) "On the application by courts of legislation on copyright and related rights" and the decision of the Plenum of the Supreme Economic of the Court of Ukraine of October 17, 2012 (Resolution No. 12, 2012) "On some issues of dispute resolution practice related to the protection of intellectual property rights", which, inter alia, states how to qualify the placement of works on the Internet in a form accessible for public use.

The subject of intellectual property is also regulated by the Law of Ukraine "On Copyright and Related Rights" (Law No. 3792-XII,1993), which enshrines and protects the personal nonproperty and property rights of authors, their successors and performers, producers of phonograms and videograms, and broadcasting organizations. The Law of Ukraine "On Television and Radio Broadcasting" (Law No. 3759-XII, 1993) defines the concept of transmission (television and radio transmission) and program (television program).

Among the bylaws is the Resolution of the Cabinet of Ministers of Ukraine "On the establishment of the Council on Intellectual Property" of February 7, 2018, No. 90, which establishes the body of the same name, whose task is to promote coordination of executive authorities in the field of intellectual property, identify ways overcoming problems that arise in this area, preparation of recommendations and proposals, etc.

The presence of a significant number of international and national regulations related to the protection of intellectual property rights necessitates the systematization of existing rules and the allocation of key provisions that can help solve urgent problems of intellectual property protection on the Internet, as underdeveloped terminology and significant gaps in the legal regulation of certain objects related to intellectual property rights on the Internet (as will be noted below) lead to serious problems in the field of protection and enforcement of intellectual property rights.

\section{Intellectual property rights on the Internet: the} main problems and ways to solve them

The constant growth of Internet users around the world has led to the emergence of so-called Internet offenses, including those related to intellectual property rights. The situation at the international level is complicated by the lack of provisions of international regulations that would regulate the protection of intellectual property rights on the Internet. Most of these acts were adopted in the early to mid-twentieth century, and therefore to predict all the problems that will arise with the development of the Internet was not possible. However, some researchers believe that to protect intellectual property rights on the 
Internet, the adoption of new international instruments is still not a way out of this situation. Instead, they propose to resolve issues at the national level.

This point of view is primarily related to the first problem of protection of intellectual property rights on the Internet - the unsuitability of the concept of the place of the offense to cyberspace. The fact is that many Internet resources currently use domain names that are registered to residents of offshore countries to distribute illegal content that violates the property rights of certain legal entities or individuals, making them inaccessible to international law enforcement and judicial authorities in Europe and the USA. Taking advantage of the fact that traditional justice requires a lawsuit at the location of the defendant, those who post illegal content in this way virtually eliminate all opportunities for rights holders to obtain fair compensation in court.

The most common infringements of intellectual property rights on the Internet are (Sotnyk, 2021):

1) The use as a component of a domain name of a name that is identical or similar to the level of mixing with a registered trademark, followed by the use of such a domain for commercial purposes (so-called domain disputes).

The legislative definition of the term "domain" is contained in the Law of Ukraine "On Telecommunications" (Law No. 1280-IV, 2003). According to Part 1 of Article 1 of this Law, a domain is a part of the hierarchical address space of the Internet that has a unique name that identifies it, is serviced by a group of domain name servers, and is centrally administered. The same article defines that a domain can have several levels, in particular: domain.UA - the top-level domain of the hierarchical address space of the Internet, created based on coding country names following international standards, to serve the address space of the Ukrainian segment of the Internet; second-level domain part of the address space of the Internet, located at the second level of the hierarchy of names in this network.

As for the actual domain name, under para. 15 art. 1 of the Law of Ukraine "On Protection of Rights to Marks for Goods and Services" domain name is a name used to address computers and resources on the Internet (Law No. 3689-XII, 1993).
At the international level, issues related to domain names are regulated by the following documents:

- WIPO Report " The Management of Internet Names and Addresses: Intellectual Property Issues" (1999);

- Joint Recommendation on the Protection of Well-known Marks, adopted by the Paris Union Assembly for the Protection of Industrial Property and the General Assembly of the World Intellectual Property Organization at the 34th series of meetings of the Assembly of the Member States of the World Intellectual Property Organization on 20-29 September 1999;

- Joint Recommendation "On the Protection of Marks and Other Industrial Property Rights on Internet Designations", adopted by the Paris Union Assembly on Industrial Property Protection and the General Assembly of the World Intellectual Property Organization at the 36th meeting of the Assembly of Member States of the World Intellectual Property Organization property September 24 - October 3, 2001.

Based on the case-law on disputes related to domain names, it is possible to identify mechanisms for the protection of intellectual property rights in domain disputes:

I. protection of rights in civil, commercial, administrative, and criminal proceedings. In the literature, one can find the idea of appealing to law enforcement agencies to initiate a criminal case as an additional type of protection of intellectual property rights (Bukhtiyarov, 2021);

II. appeal to the bodies of the Antimonopoly Committee.

III. appeal to the arbitral tribunal, application of the Uniform Domain Name Dispute Resolution Policy (UDRP), (Coordination Council of the Ukrainian Network Information Center, 2013), it is possible to resolve disputes out of court by applying to the Commission for Pre-trial Resolution of Domain Disputes, which is formed on the initiative of the ".UKR" domain administrator.

\section{2) Violation of industrial design rights.}

In the context of this type of intellectual property infringement, it should be noted that an industrial design on the Internet may be protected as the appearance of a particular industrial product (drawing or coloring or a combination thereof) 


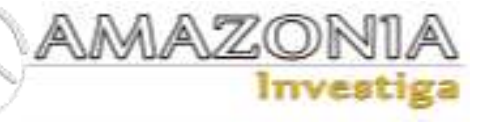

hosted on a website on the Internet, and the graphical interface of the website itself, through which the user of the website interacts with complex computer programs.

According to Law No. 3792-XII, a website is a set of data, electronic (digital) information, other objects of copyright and (or) related rights, etc., related to each other and structured within the address of the website and (or) the account of the owner of this website, which is accessed through the Internet address, which may consist of a domain name, directory or call records and (or) a numerical address according to the Internet Protocol.

According to Zerov $(2013,2018)$, it is advisable to consider the website through its division into the front end (what the user sees) - design, content; and back end (what is hosted on the server) part. Website design can receive legal protection as a work of fine art or industrial design (GUI). Also, a similar position on the content of the website is expressed in the Guidelines for employees of legal services (legal advisers) of executive authorities, state enterprises, institutions and organizations "Website as an object of intellectual property relations", where one of the components of the website there is information content. It is the information content of the sites that attract the attention of visitors, and it is the most valuable for the site owner. The content of the site consists of text, graphics, and audiovisual materials. They are all subject to copyright, which means that their copyrights can be registered separately. In addition, property and non-property rights to each of these objects may belong to different persons (Ukraine, The Ministry of Justice, 2016). 3) Illegal publication or posting on the Internet for illegal downloading of copyright objects (journalistic works, programs, video, audio products, etc.) - the so-called "piracy".

The main area of infringement of intellectual property rights on the Internet was and remains the so-called "piracy". Art. 50 of the Law "On Copyright and Related Rights" (Law No. 3792XII, 1993) establishes the definition of piracy in the field of copyright and (or) related rights publication, reproduction, import into the customs territory of Ukraine, export from the customs territory of Ukraine, and distribution of counterfeit copies of works (including computer programs and databases), phonograms, videograms, illegal disclosure of programs of broadcasting organizations, camcording, card sharing, as well as Internet piracy, i.e. the commission of any actions that are recognized under this article as a violation of copyright and (or) related rights using the Internet. Piracy, according to this article, is a violation of copyright and (or) related rights, which gives grounds for protection, including judicial, of such rights.

Contribute to the spread of Internet piracy and advertising, which is purchased by well-known brands and which is placed automatically, including on pirated sites, and the availability of content for ordinary users. Due to this, Internet piracy is thriving not only in Ukraine but all over the world, but the methods of combating it differ. The practice of shifting responsibility to ISPs for preventing the distribution of illegal content and controlling such distribution is becoming widespread. In particular, Grigoryants (2014), analyzing the experience of foreign countries, reveals popular mechanisms to combat Internet piracy. In Canada, for example, a copyright holder has the right to contact an ISP to report that a subscriber has made available content that infringes the copyright or related rights. The provider, in turn, sends such a subscriber a warning and monitors its activities for a definite time, after which, if illegal content has not been removed, the subject of copyright or related rights has the right to sue the provider to disclose such subscriber's data, and then about the elimination of content and protection of infringed rights. In France, the United Kingdom, and Germany, the researcher points out, that there is also a mechanism for declassifying subscriber data, which provides access to infringing content at the request of a court or a specialized body for copyright and related rights on the Internet. In Ukraine, a non-profit organization, the Ukrainian Anti-Piracy Association, was established to combat Internet piracy. In particular, they created a particular site, which contains a list of sites to which rights holders have complaints about the illegal placement of content, and which is constantly updated. Thus, when buying advertising, brands may ignore such sites, and, thus, not support Internet piracy. There is also the Clean Sky Initiative, which cooperates with cyberpolice in its activities to combat Internet piracy, supports public information about sites and providers to which rights holders have claims, etc.

At the same time, if we compare the legislative experience of European countries and Ukraine, in our country at the legislative level there is no obligation for Internet providers to monitor the activities of subscribers and provide information about customers (only by court decision) at the request of rights holders. 
Thus, there are several significant problems associated with the protection and enforcement of intellectual property rights on the Internet. First, there is a lack of legislation that would oblige providers to respond to the distribution by subscribers of content that infringes a copyright and related rights of rights holders. When establishing such a mechanism, it should be borne in mind that providing providers with the opportunity to disclose information about subscribers at the request of right holders without a prior court decision or permission of a public authority may adversely affect the confidentiality of user data on the Internet.

Instead, the introduction of too complicated a procedure for obtaining such a permit can lead to lengthy legal and extrajudicial delays, which will also not contribute to the effective protection of the rights of rights holders.
Secondly, the lack of government agencies that deal with the problems of Internet piracy. Currently, as described above, there are nonprofit organizations that fight against Internet piracy. However, due to the fact that such bodies are not state-owned, there is no constant informing of the public about their activities, which negatively affects the awareness of citizens about this problem and the consequences it entails.

In addition, for an effective mechanism for the protection of intellectual property rights, a necessary element is the fixation of the offense. Researchers who studied the protection of intellectual property rights on the Internet concluded the list of actions that certify these offenses. Thus, there are visual and technical ways to record infringements of intellectual property rights on the Internet (Table 1).

Table 1.

The methods of recording the offense of intellectual property rights on the Internet.

\section{The method of recording the offense}

Print a web page

Audio or video review of a web page review

Web page overview:

- court;

- a lawyer;

- by any interested person.

\section{Characteristic}

Providing the court with a web-screenshot of the web page and acknowledging it as written evidence. This type of evidence is possible if it is not objected to by the other party to the dispute (Resolution of the Plenum of the Supreme Economic Court of Ukraine No. 12, 2012)

Such a record is submitted to the court on an electronic or another media (computer hard disk, diskette, disk for laser reading systems, other media) indicating who, when, and under what conditions was the record. In this case, the court recognizes the evidence as material.

Such a right of the court is provided by the provisions of the Commercial and Civil Procedure Codes of Ukraine (Article 140 of the Civil Procedure Code (Law No. 1618-IV, 2004), Article 39 of the Commercial Procedure Code (Law No. 1798-XII, 1991), according to which material and written evidence cannot be delivered to the court are examined at their location. This location is the Internet, so the judge, if technically possible, can view the web page.

The lawyer has the right to collect information about the facts that can be used as evidence following paragraph 7. Part 1 of Art. 20 of the Law "On Advocacy and Advocacy" (Law No. 5076-VI, 2012).

Any interested person has the right to view the website on which the dispute is resolved, based on the Resolution of the Plenum of the Supreme Economic Court of Ukraine of October 17, 2012, No. 12. These inspections must be certified by an appropriate protocol.

The technical methods of recording infringement of intellectual property rights on the Internet include (Table 2): 
Table 2. Technical methods of recording infringement of intellectual property rights on the Internet.

During the expert research in the field of telecommunications, the
following actions are performed: verification of the domain name (the
expert determines whether there is a website with the appropriate domain
name on the Internet on the date of the research and whether it is
connected correctly); fixing a redirect to another domain name (if any);
fixation of the data received using the WHOIS service (the expert
establishes data on date of registration of the domain name, date of
modification of the last changes, about the domain administrator);
determining the IP address to which the domain name corresponds;
recording data about the company that provides hosting services for this
domain name; checking the correctness of the display of the content of
the website; display the main page; go to and record pages that contain
intellectual property or information relevant to research fixation of audio,
video or text files placed on the website that are important for research
research
(this type of research is extremely relevant in copyright infringement on
the Internet); fixing of all web-site if it is necessary (Order of the
Ministry of Justice of Ukraine No. 53/5, 1998).
These certificates may contain information about subjects that have
committed acts that are considered copyright infringement.

Use of the service

InternetAr chive. Way

backMachine (Internet

Archive / Digital Library

of Free Books, Movies,

The service captures the content of individual web pages offline. This

Music \& Wayback

Machine, 2021).

Instant fixing of web pages with the help of private online services service has the status of a library and is subject to US law.

The tables (Table 1 and Table 2) are compiled by authors based on the analysis of scientific works of Zerov (2013, 2018), Kovalenko (2018), Yanitska, Ambrush, \& Koval (2019), Litavskay (2020), and Zheleznyakova (2021).

In the context of changes in intellectual property rights, the judgment of the Court of Justice of the European Union in the case of VG Bild-Kunst v. Foundation Preusßischer Kulturbesitz (2021). One of the principal solutions was that in the chaotic dematerialized Internet sphere, the only way to restrict access to the author's work is to establish actual restrictions, technological "fences" or "walls". This approach does not violate other rights, such as fundamental rights, mainly freedom of expression. The Court of Justice of the European Union noted in its judgment that hyperlinks, whether used in connection with framing techniques or not, contribute to the smooth functioning of the Internet, which is of particular importance for freedom of speech and information. "

It can be argued that this position of the Court of Justice of the European Union implicitly confirms the tendency to recognize the lack of technological restrictions on access to Internet content as a basis for legal access.

\section{Conclusions}

As a result of the study, the following conclusions were made.

Despite the complexity of solving the problem of protection of intellectual property rights on the Internet, legal doctrine and legislators at both national and international levels develop provisions that address many unresolved issues in the field of protection of intellectual property rights on the Internet, such as the lack of specialized litigation in the field of intellectual property (improving criminal, civil, commercial proceedings by regulating crimes in the relevant codes; procedural assistance, in particular, in the form of providing such actions as printing and audio or video recording of the web page status of evidence), low legal culture, which is manifested in the confidence of Internet users in the natural right to be free of charge consumers of intellectual property rights, which in turn creates a proposal for the illegal distribution of intellectual property (it is necessary to complete 
the formation of legislation basis for ensuring the functioning of relations in the field of intellectual property.

There are proposals to refer all disputes related to intellectual property to the jurisdiction of the commercial court. The basis for such beliefs is the fact of the high qualification of judges who have specific knowledge. Today, these cases, their preparation for consideration, consideration, and decision-making are perhaps the most complex in terms of even technology, so we need extensive, large, and structured legislation, which includes the implemented rules of international instruments, insufficient funding for measures to combat the illegal distribution of intellectual property (funding of public organizations from the state budget would expand their scope and open new programs and initiatives. Such organizations under the auspices of government agencies would have the opportunity to cooperate with foreign authorities and organizations to jointly develop options for solving the problem of Internet piracy).

Based on the above, it would be appropriate to identify proposals to improve the protection of intellectual property rights on the Internet:

- legislative improvement of the norms of regulation of the sphere of intellectual property on the Internet through the use of foreign experience in this field;

- $\quad$ raising the legal culture of citizens;

- creation of specialized legal proceedings;

- financing of the system of protection of intellectual property rights from the state budget or other sources not prohibited by law.

In addition, it is necessary to move in this direction during further research.

\section{Bibliographic references}

Boshytsky, Yu. L. (2002). Deepening of legal culture of citizens as a means of optimization of protection of intellectual property in Ukraine. Problems of intellectual property law. Journal of Kyiv University of Law, 2, 14-22.

Bukhtiyarov, D. (2021). Domain disputes in Ukrainian realities. Legal It Group. Recovered from https://legalitgroup.com/domenni-sporyukraine/

Coordination Council of the Ukrainian Network Information Center. (2013). Temporary rules of registration and use of domain names in the ".UKR" domain. Recovered from https://nkrzi.gov.ua/images/upload/287/4258/0a 7cbe98279cdd8e2fa76b42fc626165.pdf

Court of Justice of the European Union. (2021). VG Bild-Kunst v. Foundation Preusßischer Kulturbesitz: Judgment. Recovered from https://curia.europa.eu/juris/document/document .jsf?text $=\&$ docid $=238661 \&$ pageIndex $=0 \&$ docla ng $=\mathrm{EN} \&$ mode $=$ req \&dir $=\&$ occ $=$ first $\&$ part $=1 \& \mathrm{ci}$ $\mathrm{d}=4182944$

Grigoryants, G.I. (2014). Protection of copyright and related rights against piracy on the Internet under the laws of Ukraine and the Russian Federation. Actual problems of state and law, 72, 236-242.Recovered from http://nbuv.gov.ua/UJRN/apdp_2014_72_36

Inshin, M.I. (2008). Current state and ways to improve the relationship between public authorities and the media. Sumy: Environment.

Internet Archive / Digital Library of Free Books, Movies, Music \& Wayback Machine. (2021). The official web-site. Recovered from https://archive.org

Kharytonov, E., Kharytonova, O., Kolodin, D., \& Tkalych, M. (2020). The Covid-19 Pandemic and the Rights of the Individual in Terms of Private and Public Law. Ius Humani. Law Journal, 9(2), 225-250.

DOI:

https://doi.org/10.31207/ih.v9i2.253

Kovalenko, I.A. (2018). Actual problems of protection and protection of intellectual property rights on the Internet In the context of globalization of society and modern technologies. Scientific notes of Tavriya National University named after Vernadsky: legal sciences, 29(68), 52-55. Recovered from https://er.knutd.edu.ua/bitstream/123456789/17 196/1/20210222_302.pdf

Law No. 1280-IV, On telecommunications. Bulletin of the Verkhovna Rada of Ukraine, Kyiv, Ukraine, November 18, 2003. Recovered from

https://zakon.rada.gov.ua/laws/show/128015\#Text

Law No. 1618-IV, Civil Procedure Code of Ukraine. Bulletin of the Verkhovna Rada of Ukraine, Kyiv, Ukraine, March 18, 2004. Recovered from https://zakon.rada.gov.ua/laws/show/161815\#Text

Law No. 1798-XII, Commercial Procedural Code of Ukraine. Bulletin of the Verkhovna Rada of Ukraine, Kyiv, Ukraine, November 6, 1991. Recovered from https://zakon.rada.gov.ua/laws/show/1798-

12\#Text

Law No. 2341-III, Criminal Code of Ukraine. Bulletin of the Verkhovna Rada of Ukraine, Kyiv, Ukraine, April 5, 2001. Recovered from 


\section{AMAZONDA}

https://zakon.rada.gov.ua/laws/show/234114/conv\#n2649

Law No. 254к/96-BP, Constitution of Ukraine. Bulletin of the Verkhovna Rada of Ukraine, Kyiv, Ukraine, June 28, 1996. Recovered from https://zakon.rada.gov.ua/laws/show/254\%D0\% BA/96-\%D0\%B2\%D1\%80\#Text.

Law No. 3689-XII, On protection of the rights to marks for the goods and services. Bulletin of the Verkhovna Rada of Ukraine, Kyiv, Ukraine, December 15, 1993. Recovered from https://zakon.rada.gov.ua/laws/show/3689-

12\#Text

Law No. 3759-XII, On television and radio broadcasting. Bulletin of the Verkhovna Rada of Ukraine, Kyiv, Ukraine, December 21, 1993. Recovered from https://zakon.rada.gov.ua/laws/show/375912\#Text

Law No. 3792-XII, On copyright and related rights. Bulletin of the Verkhovna Rada of Ukraine, Kyiv, Ukraine, December 23, 1993. Recovered from https://zakon.rada.gov.ua/laws/show/3792-12 Law No. 435-IV, Civil Code of Ukraine. Bulletin of the Verkhovna Rada of Ukraine, Kyiv, Ukraine, January 16, 2003. Recovered from https://zakon.rada.gov.ua/laws/show/43515\#Text

Law No. 436-IV, Commercial Code of Ukraine. Bulletin of the Verkhovna Rada of Ukraine, Kyiv, Ukraine, January 16, 2003. Recovered from https://zakon.rada.gov.ua/laws/show/436$15 \#$ Text

Law No. 5076-VI, On advocacy and advocate activity. Bulletin of the Verkhovna Rada of Ukraine, Kyiv, Ukraine, July 5, 2012. Recovered from

https://zakon.rada.gov.ua/laws/show/507617\#Text

Law No. 8073-10, Code of Ukraine on Administrative Offenses. Bulletin of the Verkhovna Rada of Ukraine, Kyiv, Ukraine, December 7, 1984. Recovered from https://zakon.rada.gov.ua/laws/show/8073110\#Text.

Litavsky, T. (2020). IP protection on the Internet: how should it theoretically work? Legal newspaper Online. Recovered from https://yurgazeta.com/publications/practice/zahistintelektualnoyi-vlasnosti-avtorske-pravo/zahistiv-u-merezhi-internet-yak-ce-teoretichno-maepracyuvati.html

Mind. (2020). The number of Internet users in the world has reached 4.8 billion. Recovered from https://mind.ua/news/20219912-kilkist-internetkoristuvachiv-u-sviti-dosyagla-48-mlrd Order of the Ministry of Justice of Ukraine No. $53 / 5$, Instruction on the appointment and conduct of forensic examinations and expert research and Scientific and methodological recommendations on the preparation and appointment of forensic examinations and expert research. Bulletin of the Verkhovna Rada of Ukraine, Kyiv, Ukraine, October 8, 1998. Recovered from https://zakon.rada.gov.ua/laws/show/z0705-

98\#Text

Paris Union Assembly for the Protection of Industrial Property, \& the General Assembly of the World Intellectual Property Organization. (1999). Protection of Well-known Marks: Recommendation. Recovered from https://www.wipo.int/edocs/pubdocs/en/marks/8 33/pub833.pdf.

Paris Union Assembly on Industrial Property Protection, \& the General Assembly of the World Intellectual Property Organization. (2001). On the Protection of Marks and Other Industrial Property Rights on Internet Designations: Recommendation. Recovered from https://www.wipo.int/edocs/pubdocs/en/marks/8 45/pub845.pdf

Petrovsky, S.V. (2002). Legal regulation of the provision of Internet services. Russian Law Academy of the Ministry of Justice of the Russian Federation, Moscow. Recovered from http://www.lib.ua-ru.net/diss/cont/100565.html Republic of Uzbekistan, \& Ukraine. (1998). Agreement between the Cabinet of Ministers of Ukraine and the Government of the Republic of Uzbekistan on cooperation in the field of protection of intellectual property rights. Recovered from https://zakon.rada.gov.ua/laws/show/860_115\#T ext

Resolution of the Cabinet of Ministers of Ukraine No. 90, On the establishment of the Council on Intellectual Property. Bulletin of the Verkhovna Rada of Ukraine, Kyiv, Ukraine, February 7, $2018 . \quad$ Recovered from https://zakon.rada.gov.ua/laws/show/90-2018$\%$ D0\%BF\#Text

Resolution of the Plenum of the Supreme Court No. 5 "On the application by courts of the law in cases of protection of copyright and related rights". Bulletin of the Verkhovna Rada of Ukraine, Kyiv, Ukraine, June 4, 2010. Recovered from

http://zakon3.rada.gov.ua/laws/show/v000570010/print1444415769881869

Resolution of the Plenum of the Supreme Economic Court of Ukraine No. 12, On some issues of dispute resolution practice related to the protection of intellectual property rights. Bulletin of the Verkhovna Rada of Ukraine, Kyiv, Ukraine, October 17, 2012. Recovered from https://zakon.rada.gov.ua/laws/show/v001260012\#Text 
Sotnyk, O.S. (2021). Internet as a risk area: infringement of intellectual property rights. Recovered from https://fileview.fwdcdn.com/?url=https\%3A\%2 F\%2Fmail.ukr.net\%2Fapi\%2Fpublic\%2Ffile_vi ew\%2Flist\%3Ftoken\%3DfxDN5cULzjVnXQa2 O4R_KTERI3KIlcMYyGwAixNLyCpJRu70M 8VIXzpVEDHpb545s0MfAxifrOtiadAs1JWRU bD1NWPhu-

6NmtjQNMYr6HwO3XA\%253AbbzJa5hxjjFX kQqH\%26r\%3D1622994492167\&default_mode $=$ view $\&$ lang $=$ uk\#start $=0$

Ukraine, The Ministry of Justice. (2016). Methodical recommendations for employees of legal services (legal advisers) of executive authorities, state enterprises, institutions and organizations "Website as an object of intellectual property relations". Recovered from http://www.justice-

km.gov.ua/uploads/files/web-sait.docx

Ukrainian Anti-Piracy Association. (2021). The official web-site. Recovered from https://apo.kiev.ua/

United Nations. (1950). Convention for the Protection of Human Rights and Fundamental Freedoms. Recovered from https://zakon.rada.gov.ua/laws/show/995_004\#T ext

World Intellectual Property Organization. (1961). International Convention for the Protection of Performers, Producers of Phonograms and Broadcasting Organisations. Recovered from https://www.wipo.int/publications/en/details.jsp ?id=320\&plang=RU

World Intellectual Property Organization. (1967). Convention Establishing the World Intellectual Property Organization. Recovered from

https://www.wipo.int/treaties/en/convention/

World Intellectual Property Organization. (1971). Strasbourg Agreement Concerning the International Patent Classification. Recovered from

https://www.wipo.int/treaties/en/classification/st rasbourg/
World Intellectual Property Organization. (1996). WIPO Performances and Phonograms Treaty. Recovered from https://www.wipo.int/treaties/en/ip/wppt/

World Intellectual Property Organization. (1999). The Management of Internet Names and Addresses: Intellectual Property Issues. Recovered from https://www.wipo.int/export/sites/www/amc/en/ docs/annex09.pdf

World Intellectual Property Organization. (2000). Patent Law Treaty. Recovered from https://www.wipo.int/treaties/en/ip/plt/

Yanitska, O.L., Ambrush, G.L., \& Koval, O.M. (2019). Some problems of copyright protection on the Internet. Legal scientific electronic journal, $1, \quad 147-150 . \quad$ DOI https://doi.org/10.32782/2524-0374/2019-6/33.

Recovered from

http://www.lsej.org.ua/6_2019/35.pdf

Zerov, K. Yu. (2013). Website as an unnamed object of copyright. Scientific Bulletin of the International Humanities University: Jurisprudence, 6-3(2), 28-30. Recovered from http://vestnik-

pravo.mgu.od.ua/archive/juspradenc6-3-

2/07.pdf

Zerov, K.O. (2016). Fixation of the content of a web page on the Internet as an element of exercising the right to copyright protection of works posted on the Internet. Monthly professional magazine "Lawyer". Recovered from https://iadvocate.com.ua/fiksatsiya-zmistuveb-storinky-v-merezhi-internet-yak-elementzdijsnennya-prava-na-zahyst-avtorskyh-pravna-tvory-shho-rozmishheni-v-merezhi-internet/ Zerov, K.O. (2018). Features of protection of copyright on works posted on the Internet. Kyiv: Interservice.

Zheleznyakova I. (2021). How to protect trademarks on the Internet. Price Control. Recovered from https://www.pricecontrol.com.ua/kak-zashhitittovarnye-znaki-v-internete/ 